\title{
ANALISIS DAMPAK PROGRAM SIMPANAN KESEJAHTERAAN SOSIAL (PSKS) TERHADAP MASYARAKAT MISKIN DI KELURAHAN BANGUNSARI, KECAMATAN DOLOPO, KABUPATEN MADIUN 2014
}

\author{
Chandra Hakim*
}

\begin{abstract}
Abstrak
$\mathrm{P}$ enelitian ini didasarkan pada program dana bantuan Program Simpanan Keluarga Sejahtera (PSKS) di Kelurahan Bangunsari, Kecamatan Dolopo, Kabupaten Madiun. Program ini merupakan program pengurangan kemiskinan dari Pemerintah Pusat sesuai amanat UUD 45 dan Pancasila. Penelitian ini bertujuan untuk mendeskripsikan pelaksanaan, evaluasi, dampak penyaluran bantuan, dan hambatan beserta faktor pendukung dilaksanakannya program PSKS di Kelurahan Bangunsari. Perolehan data pada penelitian ini melalui teknik pengumpulan data dengan observasi, wawancara, dan dokumentasi (berupa data kualitatif). Hasil penelitian menunjukkan bahwa pelaksanaan terbagi atas 4 tahap yaitu, persiapan pelaksanaan, pendataan sasaran penerima, penyebaran undangan penerima dan pengambilan dana bantuan. Evaluasi dilaksanakannya program ini di Kelurahan Bangunsari terdapat 2 hal yaitu 1)ketidaktepatan sasaran penerima bantuan dan 2) keefektifan program ini terkait dengan upaya pengurangan kemiskinan. Dampak dilaksakannya program PSKS ini yaitu (1) dampak jangka pendek terkai tmanfaat program ini terhadap efek kenaikan harga BBM yang diikuti kenaikan kebutuhan bahan-bahan pokok dan (2) dampak jangka panjang terkait lemahnya efek kemampuan program ini dalam upaya pengurangan kemiskinan. Selain itu, ada 2 dampak lain yaitu, (1) dampak positif terkait dengan manfaat program bantuan dana ini sebagai pemenuhan kebutuhan mendesak masyarakat karena naiknya harga BBM yang diikuti oleh kenaikan harga bahan pokok. dan (2) dampak negative terkait dengan munculnya sifat ketergantungan masyarakat terhadap pemerintah yang memunculkan kecemburuan social terhadap penerima bantuan. Hambatan dilaksanakannya program ini adalah permasalahan tepat dan tidak tepatnya program dan faktor pendukungnya adalah kooperatif semua komponen masyarakat dan pemerintah Kelurahan (juga Kecamatan, Polsek dan Koramil).
\end{abstract}

Kata Kunci:Simpanan Kesejahteraan Sosial dan Keluarga Miskin

* Mahasiswa Prodi PPKn IKIP PGRI Madiun 
PENDAHULUAN

Pembangunan nasional yang dilaksanakan adalah manifestasi tanggung jawab kebangsaan dalam mewujudkan cita-cita kemerdekaan bangsa Indonesia. Pembangunan dilaksanakan oleh pemerintah bersama masyarakat merupakan upaya pengejewantahan salah satu cita-cita nasional, yaitu keadilan sosial bagi seluruh rakyat Indonesia yang tercantum dalam pembukaan Undang-Undang Dasar 1945 dan sila ke-5 Pancasila yang berbunyi "Keadilan Sosial bagi Seluruh Rakyat Indonesia”.Untuk itu, pemerintah selaku pemegang amanat dari Undang-undang mengupayakan pemerataan kesejahteraan masyarakat bagi seluruh rakyat Indonesia. Keterpurukan

ekonomi yang terjadi pada tahun 1998 yaitu krisis ekonomi telah memberikan hantaman yang besar terhadap perekonomian nasional, termasuk meningkatnya angka kemiskinan masyarakat yang saat itu naik menjadi 49,50 juta atau sekitar $24,23 \%$ dari jumlah penduduk Indonesia. Untuk mengurangi angka kemiskinan akibat krisis ekonomi tersebut, pemerintah menetapkan upaya penanggulangan kemiskinan sebagai salah satu prioritas kebijakan yang diambil oleh pemerintah Indonesia. Pemerintah memiliki berbagai program penanggulangan kemiskinan yang terintegrasi mulai dari program penanggulangan kemiskinan berbasis bantuan sosial, program penanggulangan kemiskinan yang berbasis pemberdayaan masyarakat serta program penanggulangan kemiskinan yang berbasis pemberdayaan usaha kecil, yang dijalankan oleh berbagai elemen pemerintah baik pusat maupun daerah.

$$
\text { Untuk meningkatkan }
$$

efektifitas upaya penanggulangan kemiskinan, presiden telah mengeluarkan Perpres No. 15 Tahun 2010 tentang Percepatan Penanggulangan Kemiskinan, yang bertujuan untuk mempercepat penurunan angka kemiskinan hingga $8 \%$ sampai $10 \%$ pada akhir tahun 2014.

Salah satu kebijakan pemerintah dalam mengurangi dan mengurangi angka kemiskinan adalah dengan adanya Program Simpanan Keluarga Sejahtera (PSKS) yang diluncurkan pada 
November sampai dengan Desember 2014. Penerima berdasarkan data dari program sebelumnya yaitu Program Pendataan Perlindungan Sosial tahun 2011 yang dilakukan oleh Badan Pusat Statistik(BPS), namum data tersebut perlu diverifikasi oleh Tim Penanggulangan Pengurangan Kemiskinan (TNP2K).

Sementara itu, kondisi penduduk Indonesia belum merata kesejahteraannya dikarenakan penduduk yang tersebar di berbagai pulau. Pembangunan infrastruktur yang belum merata sehingga akses untuk pemerataan pembangunan di bidang ekonomi belum dikelola secara optimal oleh pemerintah. Hal tersebut mengakibatkan masih adanya keluarga miskin. Keluarga miskin hampir ada disetiap kabupaten/kota di Indonesia karena terjadinya ledakan jumlah penduduk setiap tahunnya. Untuk mengantisipasi adanya ledakan penduduk dari tahun ke tahun, pemerintah juga mengupayakan berbagai program penanggulangannya.

Secara umum PSKS dimaksudkan untuk mengurangi kemiskinan. Secara khusus, PSKS mempunyai target untuk menurunkan jumlah orang miskin. Ada empat strategi dalam kebijakan mengatasi kemiskinan diantaranya: memperbaiki program perlindungan sosial, meningkatkan akses dalam pelayanan dasar, memberdayakan kelompok masyarakat miskin, dan menciptakan pembangunan yang inklusif. Tujuan yang ingin dicapai dari PSKS adalah pemberian bantuan dana pemerintah untuk membangun keluarga produktif, membantu memastikan agar Rumah Tangga Miskin (RTM) dan rentan dapat menerima manfaat dari kebijakan pemerintah terkait dengan perlindungan sosial yang dilakukan oleh pemerintah.

Keberhasilan atau kegagalan dalam PSKS sangat bergantung pada persiapan dan koordinasi pelaksanaan program yang dilakukan pemerintah melalui pendekatan terhadap kelompok-kelompok dalam masyarakat, penyusunan kriteriakriteria penerima PSKS agar tidak terjadi gejolak dalam masyarakat, penggerakan berbagai komponen dalam mengimplementasikan kebijakan mulai dari tingkat 
pemerintah pusat, tingkat Pemerintah

Daerah kota/ kabupaten, tingkat kecamatan, tingkat kelurahan/desa sampai tingkat Rumah Tangga (RT).

Berdasarkan data pertambahan perkembangan penduduk pada Oktober 2014 di Kelurahan Bangunsari, Kecamatan Dolopo, Kabupaten Madiun berjumlah 5236 jiwa. Dengan jumlah yang ada pada bulan tersebut, ternyata masih ada 188 keluarga yang dikategorikan memiliki kriteria keluarga miskin. Oleh karena itu, perlu dilakukan langkah penelitian yang mendalam melalui penelitian ilmiah sehingga hasilnya dapat digunakan untuk menjelaskan berbagai permasalahan yang berkaitan erat dengan PSKS. Pengamatan dan penelitian ini dilaksanakan untuk mengetahui pelaksanaan, dampak, evaluasi dan hambatan serta faktor pendukung program yang sudah dan sedang dilakukan saat ini.

\section{METODE PENELITIAN}

Penelitian ini dilakukan di Kelurahan Bangunsari, Kecamatan Dolopo, Kabupaten Madiun kepada keluarga miskin penerima Program
Simpanan Keluarga Sejahtera (PSKS) yang telah ditetapkan sebagai objek penelitian. Waktu penelitian selama tiga bulan yaitu April sampai Juni2015.

$\begin{array}{ccr}\text { Yang } & \text { menjadi } & \text { sumber } \\ \text { data/informan } & \text { adalah } & \text { Kepala } \\ \text { Kelurahan dan } & \text { Petugas } & \text { Program }\end{array}$
Simpanan Keluarga Sejahtera (PSKS) di Kelurahan Bangunsari, Kecamatan Dolopo, Kabupaten Madiun. Selain itu dokumen yang berupa sumber tertulis berupa data penerima Program Simpanan Keluarga Sejahtera (PSKS) di Kelurahan Bangunsari, Kecamatan Dolopo, Kabupaten Madiun dan dokumen-dokumen lainnya.

Data yang diperoleh dalam penelitian ini ada dua macam yaitu data kuantitatif (data sekunder) berupa jumlah keluarga miskin penerima Program Simpanan Keluarga Sejahtera (PSKS), dan profil Kelurahan Bangunsari, Kecamatan Dolopo, Kabupaten Madiun dari tahun 2008-2012. Dan data kualitatif (data primer) berupa tahap-tahap pelaksanaan Program Simpanan Keluarga Sejahtera (PSKS), kemanfaatan dana bantuan PSKS oleh penerima, dan hambatan 
serta faktor pendukung pelaksanaan PSKS Kelurahan Bangunsari, Kecamatan Dolopo, Kabupaten Madiun yang diperoleh melalui wawancara, observasi dan dokumentasi.

Untuk menjamin validitas data keabsahan, dilakukan dengan triangulasi yaitu dua macam triangulasi : Triangulasi sumber yaitu kesesuaian informasi (data) yang diperoleh dari sumber informasi yang berbeda yaitu dari kepala Kelurahan Bangunsari, petugas sosialisasi program maupun keluarga miskin. Dan triangulasi teknik yaitu kesesuaian informasi yang diperoleh dengan metode yang berbeda dari sumber yang sama, yaitu antara wawancara mendalam dengan metode observasi dan metode dokumentasi.

Teknik analisis data dilakukan melalui tiga tahap yaitu Reduksi, penyajian data dan verifikasi. Reduksi data merupakan proses seleksi, merangkum, pemfokusan pada hal-hal yang penting, dicari tema dan polanya dan membuang hal-hal yang tidak perlu. Proses ini berlangsung terus sepanjang pelaksanaan penelitian.
Penyajian data merupakan suatu rakitan organisasi informasi, tersusun dalam pola hubungan sehingga akan semakin mudah dipahami. Sedangkan penarikan kesimpulan dan verifikasi yaitu, menarik kesimpulan awal yang dikemukakan dan masih bersifat sementara dan akan berubah apabila telah ditemukan lagi bukti-bukti yang kuat yang mendukung pada tahap pengumpulan data berikutnya.

\section{HASIL DAN PEMBAHASAN}

A. Pelaksanaan Program PSKS di Kelurahan Bangunsari

Adapun pelaksanaan program ini terdiri dari tahap-tahap berikut ini:

1. Tahap pertama yaitu rapat koordinasi di tingkat Kecamatan Dolopo dengan melibatkan seluruh Kepala Desa/ Kelurahan di lingkungan Kecamatan Dolopo, Polsek Dolopo (Babinkamtibmas) dan Koramil (Babinsa) sebagai pihak keamanan saat pengambilan dana bantuan di kantor pos nantinya, dan pihak kantor pos unit Kecamatan Dolopo. 
2. Tahap kedua yaitu pendataan peserta yang dilakukan oleh petugas Kelurahan (TSKS).

3. Tahap ketiga adalah penyebaran undangan dari kantor pos bagi $188 \mathrm{KK}$ yang telah didata sebagai penerima bantuan oleh petugas kelurahan.

4. Tahap terakhir adalah pengambilan danabantuan. Tahap ini dimulai tanggal 3 Desember 2014 sebagaimana yang telah diatur oleh Pemerintah Kabupaten Madiun yang berkoordinasi dengan pihak Kantor Pos Madiun. Untuk Kecamatan Dolopo, waktu pengambilan mulai tanggal 3 Desember 2014.

B. Evaluasi Pelaksanaan Program Bantuan PSKS di Kelurahan Bangunsari.

Evaluasi yang pertama terkait dengan ketidaktepatan sasaran program bantuan PSKS.Masalah yang muncul dari data sebelumnya mengacu pada 2 hal yaitu Data ini bersifat top down, yaitu data ini dibuat, diolah dan diputuskan oleh pemerintah pusat. Dan data ini pada saat pendataannya tidak melibatkan pemerintah lokal setempat yaitu pemerintah desa atau bahkan hingga tingkat RT/ RW, yang secara konkrit paling mengetahui kondisi masyarakatnya.

Kondisi inilah yang menyebabkan pelaksanaan PSKS tidak tepat sasaran.Hal ini menyebabkan timbulnya masalah sosial baru yaitu:

1. Kecemburuan sosial diantara masyarakat penerima dan masyarakat yang tidak menerima program bantuan. Masyarakat yang merasa dirinya seharusnya menerima mencemburui masyarakat yang dirasa kurang pantas menerima bantuan.

2. Protes sosial diantara masyarakat kurang mampu pada pemerintah, yang berlanjut pada protes dari pemerintah desa setempat ke pemerintah pusat. Seperti halnya juga terjadi di Kabupaten Madiun yaitu penolakan beberapa desa atas program ini karena ada masyarakat yang tidak 
mendapatkan bantuan dana di

program-program bantuan

sebelumnya (diantaranya

adalah Kecamatan Jiwan

Madiun).

Evaluasi yang kedua terkait dengan keefektifan program ini sebagai program pemerintah yang bertujuan untuk pengurangan kemiskinan.

Efektifitas program ini ditunjukkan dengan keberhasilannya mengurangi kemiskinan di Indonesia dan khususnya di Kelurahan Bangunsari. Terdapat 2 pendekatan efektifitas program pengurangan kemiskinan yang telah dilakukan pemerintah (masa pemerintahan Susilo Bambang Yudhoyono) yaitu: bersifat jangka pendek dan jangka panjang. Bersifat jangka pendek yang merupakan program kompensasi kenaikan harga BBM misalnya program $\mathrm{PKH}$, BSM, Jamkesmas, Raskin, BLSM dan BOS. Bersifat jangka panjang misalnya PNPM atau Program Perluasan Dan Pengembangan Kesempatan Kerja/Padat Karya Produktif.
Program seperti ini baik secara konsep namun pelaksanaan kurang baik. Terbukti masih banyaknya kesalahan dan kekurangan dari pelaksanaan sampai pengambilan dana bantuan.

C. Dampak Penyaluran dan Bantuan PSKS terhadap Masyarakat Miskin Kelurahan Bangunsari

1. Dampak jangka pendek, yaitudana dari program ini dapat digunakan untuk memenuhi kebutuhan pokok yang saat itu melambung tinggi, naik mengikuti harga BBM yang sebelumnya naik. Selain itu, untuk modal usaha, atau kebutuhankebutuhan mendesak lainnya.

2. Dampak jangka panjang, yaitu pemberdayaan ekonomi jangka panjang untuk dapat membangun ekonomi-sosial yang produktif dan mandiri. Dampak sosial-ekonomi penyaluran dana bantuan PSKS dari sudut positif dan negatif terhadap masyarakat. Dampak positif, yaitu danadana yang disalurkan dapat untuk memenuhi kebutuhan 
pokok yang mendesak yang naik akibat harga BBM naik. Pemenuhan kebutuhan pokok yang mendesak ini berarti dapat membantu masyarakat Kelurahan Bangunsari untuk tidak terlalu terjatuh dalam kemiskinan.

Dampak negatif, yaitu penyaluran dana-dana bantuan dari pemerintah dapat menyebabkan ketergantungan masyarakat terhadap pemerintah. Ini sebagai bagian dampak jangka panjang yang tidak baik, bahwa tidak terbangunnya kondisi ekonomi yang produktif dan mandiri di tingkat masyarakat, dan yang seharusnya dilakukan adalah pemberdayaan ekonomisosial masyarakat yang berdampak jangka panjang. Selain itu, terjadinya masalah sosial baru, yaitu kecemburuan sosial masyarakat yang sebenarnya berhak menerima terhadap masyarakat yang sebenarnya tidak berhak menerima dana bantuan. Dengan sudah dilaksanakannya pemutakhiran data melalui program BDT 2015, hal ini tidak terjadi lagi.

D. Hambatan dan Faktor Pendukung Pelaksanaan Program PSKS di Kelurahan Bangunsari

1. Hambatan pelaksanaan penyaluran dana bantuan PSKS di Kelurahan Bangunsari tidak ada. Akan tetapi, hambatan muncul pada ketidaktepatan sasaran penyaluran program.

2. Faktor pendukung pelaksanaan program bantuan PSKS ini adalah sangat kooperatifnya semua masyarakat Kelurahan Bangunsari dengan pihakpihak terkait yaitu Kelurahan Bangunsari sebagai fasilitator terlaksananya program PSKS ini, Polsek (Babinkantibmas), Koramil (Babinsa) dan Kantor Pos sebagai institusi yang ditunjuk sebagai penyalur dana program bantuan PSKS ini. 
SIMPULAN

A. Pelaksanaan PSKS di Kelurahan Bangunsari, Kecamatan Dolopo, Kabupaten Madiun.

1. Tahap persiapan dan koordinasi antara Kecamatan, Desa/Kelurahan, Polsek (Babinkantibmas), Koramil (Babinsa) dan Kantor Pos.

2. Tahap pendataan penerima dana PSKS oleh petugas kelurahan.

3. Tahap penyebaran undangan kepada penerima dana PSKS.

4. Tahap pengambilan dana bantuan di kantor kelurahan tanggal 3 Desember 2014.

B. Evaluasi Pelaksanaan Program Bantuan PSKS di Kelurahan Bangunsari

1. Ketidaktepatan sasaran program bantuan PSKS, yang menyebabkan masalah baru yaitu kecemburuan sosial masyarakat yang seharusnya menerima tetapi tidak menerima dana bantuan.

2. Keefektivan program ini sebagai upaya pemerintah untuk mengurangi kemiskinan di Indonesia, karena sifat manfaat dana bantuan yang sesaat/sementara dan tidak jangka panjang (saat kenaikan harga bahan pokok karena kenaikan harga BBM).

C. Dampak Pelaksanaan Program PSKS terhadap Masyarakat Miskin di Kelurahan Bangunsari

1. Dampak jangka pendek dapat meredam gejolak sosial akibat BBM naik berikut harga-harga kebutuhan pokok yang juga ikut naik.

2. Dampak jangka panjang hanya dirasa sebagai bentuk kompensasi jangka pendek sebagai kompensasi ekonomisosial akibat kenaikan harga BBM. Dampak sosialekonomi penyaluran dana bantuan PSKS dari sudut positif dan negatif terhadap masyarakat. Dampak positif, program bantuan PSKS ini lebih merupakan manfaat pemenuhan kebutuhan saat harga-harga naik karena BBM naik. Sedangkan dampak negatif, menyebabkan ketergantungan masyarakat terhadap pemerintah dan terjadinya 
masalah sosial baru, yaitu kecemburuan sosial

masyarakat terhadap

masyarakat yang sebenarnya tidak berhak menerima dana bantuan.

D. Hambatan dan Faktor Pendukung Pelaksanaan Program PSKS di Kelurahan Bangunsari

1. Hambatannya muncul pada ketidaktepatan sasaran penyaluran program.

2. Faktor pendukungnya adalah kooperatifnya semua pihak terkait atas keseluruhan proses pelaksanaan program PSKS ini di Kelurahan Bangunsari.

\section{DAFTAR PUSTAKA}

J. Subagyo. 2004. Metode Penelitian dalam Teori dan Praktek. Jakarta: Rineka Cipta.

Lexy J. Moleong. 2012. Metodologi Penelitian Kualitatif. Bandung: Remaja Rosdakarya.

S. Djam'an. danA. Komariah. 2012. Metodologi Penelitian Kualitatif. $\quad$ Bandung: Alfabeta.

S. Nasution. 2012. Metode Research (Penelitian Ilmiah). Jakarta: Bumi Aksara.

Sugiyono. 2013. Cara Mudah Menyusun Skripsi, Tesis, dan Disertasi (STD). Bandung: Alfabeta. 2013. Metode Penelitian Kuantitatif, Kualitatif, dan $R \& D$. Bandung: Alfabeta. 